УДК 355.4

Ігор Сердійович Романченко (доктор військ. наук, професор)

Віктор Іванович Гвоздь (канд. військ. наук)

Центральний науково-досліднй інститут Збройних Сил Украӥни, Київ, Україна

\title{
КОНЦЕПТУАЛЬНІ ЗАСАДИ ОБҐРУНТУВАННЯ ВИМОГ ДО СИСТЕМИ ІНФОРМАЦІЙНОГО ЗАБЕЗПЕЧЕННЯ СЕКТОРУ БЕЗПЕКИ I ОБОРОНИ УКРАЇНИ
}

Аналіз подій останніх років свідчить, про те щзо інформачійне забезпечення прийняття рішень 3 воєнної безпеки є вкрай важливим, однак його розвитку в Украӥні не приділяється достатньо уваги. В державі існує низка розвідувальних органів, однак зв'язки між ними слабко розвинені, щуо призводить до розпорошення їх зусиль та ресурсів. Практично відсутня координація роботи розвідувального співтовариства з боку керівництва держави, не відпрацьований порядок замовлення та оцінювання інформачї, щзо також негативно впливає на роботу розвідувальних органів.

Для усунення зазначених проблемних питань пропонується створити систему інформаційного забезпечення сектору безпеки і оборони, яка базується на принципі ієрархічності та в якій чітко встановлюються напрямки замовлення та проходження розвідувальної інформації, а також забезпечується координація зусиль ї̈ суб’єктів. Така система, на думку авторів, значно підвищить обтрунтованість рішень, які приймаються з питань забезпечення воєнної безпеки, дозволить більш раціонально використовувати ресурси та збільшить ефективність функціонування розвідувальних органів Украӥни.

Ключові слова: система інформаційного забезпечення, сектор безпеки і оборони, воєнна безпека.

\section{Вступ}

Постановка проблеми у загальному вигляді. Разом із зростанням ролі інформаційного забезпечення процесів прийняття рішень 3 питань забезпечення воєнної та національної безпеки, підвищується необхідність у створенні відповідної системи, яка б забезпечувала своєчасне надання актуальної та достовірної інформації.

Однак на теперішній час в Україні не існує такої системи в сталому вигляді. Завдання інформаційного забезпечення виконують окремі організації (розвідувальні органи), між якими відсутні зв'язки, що призводить до розпорошення зусиль та зниження ефективності їх роботи. Крім цього, відсутні зворотні зв'язки між споживачами та постачальниками інформації, не відпрацьований порядок замовлення та оцінювання інформації, що також негативно впливає на роботу розвідувальних органів.

Зазначені проблеми призвели до серйозної кризи, що охоплює практично всі сфери суспільного життя, при цьому, більшість значущих рішень, зокрема 3 питань воєнної безпеки, в сучасних умовах приймаються без глибокого i всебічного аналізу їх наслідків.

Саме тому актуальним є завдання визначення загальної структури системи інформаційного забезпечення (СI3) сектору безпеки і оборони (СБіО), а також вимог до неї та іiї складових.

Аналіз остатніх досліджень і публікацій. Останнім часом видана низка публікацій, присвячених діяльності розвідувальних співтовариств різних країн світу [1]-[6], однак концептуальні питання обгрунтування вимог до системи інформаційного забезпечення СБіО практично не розглядалися.

Мета статті полягає у викладені концептуальних положень обгрунтування вимог до СI3.

\section{Виклад основного матеріалу} дослідження.

Важливим етапом обгрунтування вимог до СI3 $€$ визначення іiі обрису та концептуального уявлення щодо процесів, які відбуваються в цій системі. Авторами у [7]-[9] розглядалися окремі концепції, які дозволяють розв'язати цю задачу.

Відповідно до концепцій: ієрархічності розвідувальної інформації у СІ3 [7], циклічності інформаційного забезпечення у системі інформаційного забезпечення [8], та єдиного розвідувального простору [9], пропонується таке схематичне бачення СІ3 України (рис. 1).

До СІЗ входять такі складові, як суб’єкти забезпечення національної (воєнної) безпеки, розвідувальні органи, координаційні органи та інформаційна інфраструктура [9]-[10]. Вони знаходяться в тісній взаємодії, а рішення з питань воєнної безпеки приймаються керівництвом держави (споживачами) з урахуванням добутої розвідувальної інформації.

Розглянемо основні аспекти запропонованої концепції.

Вважаємо, що інформаційне забезпечення (розвідувальна діяльність) є одним 3 різновидів

(C) I.C. Романченко, B.I. Гвоздь 
інформаційної роботи, основний принцип якої чіткий розподіл понять: відомості (дані), інформація й знання.

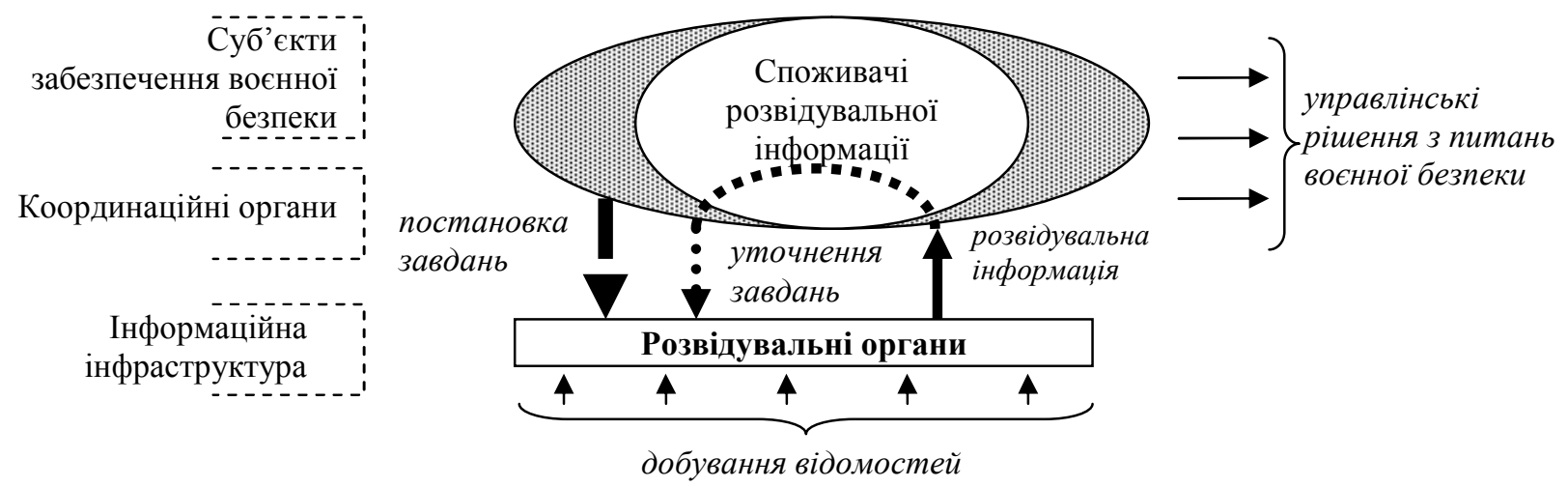

Рисунок 1 - Концептуальна схема СІЗ СБіО України (базовий варіант)
Як відомості можуть виступати статистика, уривки інформації тощо, про те що становить інтерес, однак, не можна прийняти правильне рішення, виходячи тільки з даних, незалежно від того, наскільки вони точні або об'ємні.

Інформація, навпаки, являє собою певну сукупність відомостей, які були відібрані, оброблені й проаналізовані, після чого їх можна використовувати для подальших дій.

Синтезовані рішення й рекомендації являють собою кінцевий інформаційний продукт - знання. Особі, що ухвалює рішення, потрібні саме інформація й знання, а не просто відомості.

Така градація відповідає положенням концепції ієрархічності розвідувальної інформації [7] та визначеним у ній видам діяльності (оперативна аналітика, інформаційна робота, аналітична діяльність), при цьому ланцюг виконуваних дій не змінюється незалежно від рівня інформації.

Уся інформація, що передається від розвідувальних органів до споживачів поділяється на:

- стратегічну - інформація про глобальні процеси в економіці, політиці, військовій сфері і т.д., яка можуть виявити якийнебудь вплив (позитивний або негативний) на державу. Така інформація необхідна для прийняття стратегічних рішень щодо глобальної мети розвитку держави;

- тактичну - інформація для прийняття рішень щодо оптимізації шляхів досягнення глобальної мети, з урахуванням зміни обстановки.

- оперативну - інформація для прийняття керівництвом обгрунтованих рішень щодо розв'язання поточних проблем держави.

Інформація стратегічного та тактичного характеру повинна надходити до посадових осіб, які займаються плануванням та несуть відповідальність за прийняття стратегічних рішень. Крім того, необхідно не тільки забезпечити отриманою інформацією всіх зацікавлених осіб, але й одночасно забезпечити контроль над її цільовим використанням.

У запропоновану на рис. 1 концептуальну схему закладені основні положення концепції циклічності інформаційного забезпечення [8], а саме:

- планування та постановка завдань;

- добування даних;

- обробка розвідувальних

перетворення їх у розвідувальну інформацію;

- аналіз і синтез розвідувальної інформації (перетворення іï в знання - висновки та рекомендаціі);

- розповсюдження (доведення до споживачів).

Для подальшого визначення вимог до СІ3 України пропонується поділити ії на три рівні:

- верхній, до нього відносяться суб'єкти забезпечення воєнної безпеки - споживачі розвідувальної інформації, які безпосередньо керують СІ3 та відповідають за підготовку та прийняття управлінських рішень щодо забезпечення належного ступеня воєнної безпеки держави;

- середній - на ньому здійснюється інформаційна робота та аналітична діяльність 3 оброблення отриманих розвідувальних відомостей;

- нижній - рівень, на якому добуваються розвідувальні відомості та відбувається їх первинне оперативне оброблення (оперативна аналітика).

Таким чином, схема наведена на рис. 1 перетворюється на більш деталізовану (рис. 2).

Відповідно до запропонованої схеми пропонується визначати вимоги до СІ3 за рівнями (верхній, середній, нижній). Це дозволить більш гнучко та раціонально визначати склад необхідних сил та засобів на кожному 3 рівнів, визначати потрібну ефективність ї функціонування для забезпечення належного рівня інформаційного забезпечення, якості управлінських рішень, що приймаються з питань воєнної безпеки.

Тобто, під час визначення вимог до СІ3 держави доцільно розглядати такі рівні:

- управління (верхній);

- інформаційно-аналітичний (середній);

- виконавчій (нижній).

На кожному з рівнів перелік можливостей до яких, власне, й мають визначатися вимоги.

Слід зауважити, що хоча всім рівням СI3 
притаманний єдиний набір можливостей, що суттєво полегшує дослідження, вимоги до їх значень на кожному з рівнів можуть розрізнятися.

Так, наприклад, рівень професійних якостей кадрів має більше значення на нижньому рівні порівняно $з$ якістю експертного середовища, однак на середньому рівні до них пред'являються



приблизно однакові вимоги, а на верхньому рівні професійні якості мають переваги над якістю експертного середовища.

Крім цього, вимоги до СІ3 на різних рівнях значною мірою залежать від рівня та спрямованості загроз воєнній та національній безпеці.

\section{Висновки й перспективи подальших досліджень}

Таким чином, запропонований концептуальний підхід дозволяє визначити по-перше узагальнений вигляд системи інформаційного забезпечення держави, по-друге - підхід до визначення вимог до зазначеної системи. Такий підхід полягає в послідовному ієрархічному розгляді всіх ланок СІ3 та визначенні вимог до можливостей іiі складових із добування, оброблення, накопичення та передавання інформації.

\section{Jimepamypa}

1. Пыхалов И. В. Спецслужбы США. - С-П.: Издательский Дом "Нева" Издательство "ОЛМАПРЕСС”, 2002. - 480 с. 2. Кондратов А. И. Внешнеполитическая деятельность государства и динамические категории политической науки. - М.: Граница, 2011. - 220 с. 3. Плэтт В. Информационная работа стратегической разведки. - М., 1998. - 155 с. 4. Семченко О. І. Забезпечення інформаційної безпеки держави. Підручник. - К., 2015. - 672 с. 5. Маломуж М. Розвідувальне співтовариство України не потребує нових штучних надбудов. http://cacds.org.ua/ru/comments/323. 6. Philippe M. Dans le secret des services: la France malade de ses espions?. Paris, 2007. - 464 p. 7. Романченко I. С., Гвоздь В. I.
Концепція ієрархічності розвідувальної інформації у системі інформаційного забезпечення воєнної безпеки України // Зб. наук. пр. ЦНДІ ЗС України. - К., 2017. № 3 (81). - С. 29-32. 8. Романченко I. С., Гвоздь В. І. Концепція циклічності інформаційного забезпечення у системі інформаційного забезпечення воєнної безпеки України // Зб. наук. пр. ЦНДІ ЗС України. - К., 2017. № 4 (82). - С. 31-38. 9. Романченко I.C., Гвоздь В. І. Концепція єдиного розвідувального простору держави // Зб. наук. пр. ЦНДІ ЗС України. - К., 2018. № 1 (83). С. 55-62. 10. Закон України "Про основи національної безпеки України" від 19.06.2003 № 964-IV (зі змінами). Відомості Верховної Ради України від 26.09.2003, № 39, стаття 351.

\title{
КОНЦЕПТУАЛЬНЫЕ ОСНОВЫ ОБОСНОВАНИЯ ТРЕБОВАНИЙ К СИСТЕМЕ ИНФОРМАЦИОННОГО ОБЕСПЕЧЕНИЯ СЕКТОРА БЕЗОПАСНОСТИ И ОБОРОНЫ УКРАИНЫ
}

\author{
Романченко Игорь Сергеевич (д-р воен. наук, профессор) \\ Гвоздь Виктор Иванович (канд. воен. наук)
}

\section{Центральный научно-исследовательский институт Вооруженных Сил Украӥни, Киев, Украина}

Анализ событий последних лет свидетельствует, что информачионное обеспечение принятия решений по военной безопасности крайне важно, однако его развитию в Украине не уделяется достаточно внимания. В государстве существует ряд разведывательных органов, однако связи между 
ними слабо развиты, что приводит к распьлению их усилий и ресурсов. Практически отсутствующая координачия работы разведывательного сообщества со стороны руководства государства, не отработанный порядок заказа и оценивания информации, что также отрицательно влияет на работу разведывательных органов.

Для устранения указанных проблемных вопросов предлагается создать систему информационного обеспечения сектора безопасности и обороны, которая базируется на принџипе иерархичности и 6 которой четко устанавливается порядок заказа и прохождения разведывательной информации, а также обеспечивается координация усилий ее субъектов. Такая система, по мнению авторов, значительно повысит обоснованность решений, которые принимаются по вопросам обеспечения военной безопасности, позволит более рачионально использовать ресурсы и увеличит эффективность функиионирования разведывательных органов Украины.

Ключевые слова: система информационного обеспечения, сектор безопасности и обороны, военная безопасность.

\title{
CONCEPTUAL PRINCIPLES OF PROVISION OF A RATIONALE FOR THE REQUIREMENTS FOR THE INFORMATION SUPPORT FOR THE SECURITY AND DEFENSE SECTOR OF UKRAINE
}

\author{
Romanchenko Ihor Serhiyovych (Doctor of Military Sciences, Professor) \\ Hvozd Victor Ivanovych (Candidate of Military Sciences)
}

\section{Central Research Institute of the Armed Forces of Ukraine, Kyiv, Ukraine}

The analysis of the last years' events shows that the information support to the decision making on military security is extremely important, but its development in Ukraine is not given enough attention. There are a number of intelligence agencies in the state, but cooperation between them is poorly developed, which leads to the dispersal of their efforts and resources. In fact, there is no coordination of the work of the intelligence community by the state leadership, the order of requesting and evaluation of information is not worked out, which also negatively affects the work of intelligence agencies.

In order to address these problematic issues, we propose to create a system of information support to the security and defense sector, based on the principle of hierarchy, in which the directions of requesting and passing of the intelligence information are clearly determined, and coordination of the efforts of its subjects is ensured. Such a system, in the opinion of the authors, will significantly increase the validity of the decisions taken on ensuring military security, will allow more rational use of resources and will increase the efficiency of the work of intelligence agencies in Ukraine.

Key words: information support system, security and defense sector, military security.

\section{References}

1. Pyhalov I. V. (2002), US Special Services. [Specsluzhby SShA], St. P.: Publishing Houses "Neva", "OLMA-PRESS", 480 p. 2. Kondratov A. I. (2011), Foreign Political Activity of the State and Dynamic Categories of Political Science. [Vneshnepolytycheskaja dejateljnostj ghosudarstva y dynamycheskye kateghoryy polytycheskoj nauky], M.: "Granitsa", 220 p. 3. Platt V. (1998), Informational Work of Strategic Intelligence. [Informacionnaja rabota strategicheskoj razvedki], Moscow, 1998. 155 p. 4. Semchenko O. I. (2015), Providing Information Security of the State. Textbook. [Zabezpechennja informacijnoji bezpeky derzhavy. Pidruchnyk], Kyiv, 672 p. 5. Malomuzh M. The Intelligence Community of Ukraine Does Not Need New Artificial Additional Structures. [Rozviduvaljne spivtovarystvo Ukrajiny ne potrebuje novykh shtuchnykh nadbudov], http://cacds.org.ua/en/comments/323. 6. Philippe M. (2007), Dans le secret des services: la France malade de ses espions?. Paris, 464 p. 7. Romanchenko I. S., Hvozd V. I. (2017), The Conception of Hierarchy of Intelligence Information in the System of Ukraine's Military Security Information Support. Collection of articles, Works of the Central Scientific Library of the Ukrainian Armed
Forces. [Koncepcija ijerarkhichnosti rozviduvaljnoji informaciji u systemi informacijnogho zabezpechennja vojennoji bezpeky Ukrajiny], Kyiv, 2017. Issue 3(81), P. 29-32. 8. Romanchenko I. S., Hvozd V. I. (2017), The Conception of Cyclicity of Information Support in the System of Ukraine's Military Security Information Support. Collection of articles, Works of the Central Scientific Library of the Ukrainian Armed Forces. [Koncepcija cyklichnosti informacijnogho zabezpechennja u systemi informacijnogho zabezpechennja vojennoji bezpeky Ukrajiny], Kyiv, Issue 4(82), P. 31-38. 9. Romanchenko I. S., Hvozd V. I. (2018), The Concept of a Single Intelligence Space of a State. Collection of articles, Works of the Central Scientific Library of the Ukrainian Armed Forces. [Koncepcija jedynogho rozviduvaljnogho prostoru derzhavy], Kyiv, Issue 1(83), P. 55-62. 10. Law of Ukraine "On the Principles of National Security of Ukraine" of June 19, 2003 No. 964-IV (as amended). [Pro osnovy nacionaljnoji bezpeky Ukrajiny], "Information from the Verkhovna Rada of Ukraine" of September 26, 2003, No. 39, P. 351. 